\title{
Acceptability of Sea Cucumber (Holothuria Nobilis) Food Chips and Its Nutritional Value: Inputs to Income Generating Project
}

\author{
Engr. Neil L. Egloso and Prof. Frances V. Delantar
}

\begin{abstract}
Sea cucumbers are marine animals of the class Holothuroidea. It has provided a valuable source of income for communities across the Asia-Pacific region for decades. As for now, there are no available food products in the local market that process sea cucumber into food chips from Holothuria nobilis (white teatfish) in Palompon, Leyte. Hence, this study is conducted to determine the acceptability of sea cucumber food chips as well as its nutritional value in order to improve its quality and make it a viable source for income generation
\end{abstract}

Keywords - Sea Cucumber, Holothuria Nobilis, Food Chips, Nutritional Value, Income Generating Project.

\section{BACKGROUND OF THE STUDY}

Sea cucumbers are marine animals of the class Holothuroidea. It has provided a valuable source of income for communities across the Asia-Pacific region for decades. They are used in a fresh or dried form in various cuisines. It usually prepared as delicacies and condiments for soups, noodles, and other dishes, and sometimes prepared as salads, eaten fresh or fermented. It provides an alternative livelihood that not only brings in supplemental income but also reduces pressure on wild populations.

Sea cucumber is a valuable source of substances that can serve as natural health products, extracts of desired sea cucumber materials are put to easy-to-consume formats as capsules (hard and soft gelatin) and tablets. It will also serve as rich in source of nutrients like mucopolysaccharides, mainly chondroitin sulfate, which is well known for its ability to reduce arthritis pain. Rich in protein and minerals, sea cucumbers also have curative properties for ailments such as high blood pressure, a muscular disorder, whooping cough, bronchial inflammation, and minor wounds.

These are widely distributed in all oceans of marine environments, ranging from the intertidal zone to the deepest oceanic trenches. One of the most valuable marine invertebrates which are processed into food is sea cucumber. Sea cucumbers are locally known as balat, balatan or trepang, and commercially known as beche de mer. Over 650 species of sea cucumber belong to Holothurians group but only about 14 are identified for commercial value. The white teat fish is the most expensive and generally preferred species.

Engr. Neil L. Egloso and Prof. Frances V. Delantar, Palompon Institute of Technology, Palompon, Leyte, Philippines
A traditional product of sea cucumber was a crunchy product which is a potential substitute for pork chicharon. Flavorings like garlic, ginger, and bay leaf may be added to satisfy the palate of consumers. Sensorial quality of sea cucumber chips showed that the treatment of ginger, garlic, and bay leaf had no significant effect on the flavor, odor and general acceptability of the product.

Normally, sea cucumbers are cleaned by burying under the sand overnight and washing in hot water to remove the hard covering and other impurities on their skin. These are then prepared as smoke-dried and boil-dried and are sold commercially in such forms. The sensory evaluation showed that smoke-dried sea cucumber was affected by molds after by molds after 10-12 months of storage at room temperature.

As for now, there are no available food products in the local market that process sea cucumber into food chips from Holothuria nobilis (white teatfish) in Palompon, Leyte. Hence, this study is conducted to determine the acceptability of sea cucumber food chips as well as its nutritional value in order to improve its quality and make it a viable source for income generation.

\section{SignifiCANCE OF THE StUdy}

1. It provides information to the local community about sea cucumber food chips, a special kind of food product has a potential for market viability.

2. It has socio-economic impacts to our community which provide an additional source of income and create more jobs for our local fishermen.

3. It gives vital information on its nutritive value of the sea cucumber in the market.

\section{OBJECTIVES}

\section{A. General Objective}

To determine the acceptability of sea cucumber (Holothuria nobilis) food chips and its nutritional value in order to improve its product quality and make it viable for income generation.

\section{B. Specific Objective}

1. To determine the level of acceptability of sea cucumber (Holothuria nobilis) food chips as evaluated by the food/culinary instructors, food tech. students and food caterers in terms of: 
1.1 appearance

1.2 crispiness

1.3 flavor

2. To determine the proximate nutrient analysis of the collected samples using standard method.

3. To determine the significance difference in the level of acceptability of sea cucumber food chips as evaluated by the three groups of evaluators.

\section{Hypothesis}

1. There is no significant difference in the level of acceptability of sea cucumber (Holothuria nobilis) food chips as evaluated by the three groups of evaluators.

\section{Schematic Diagram}

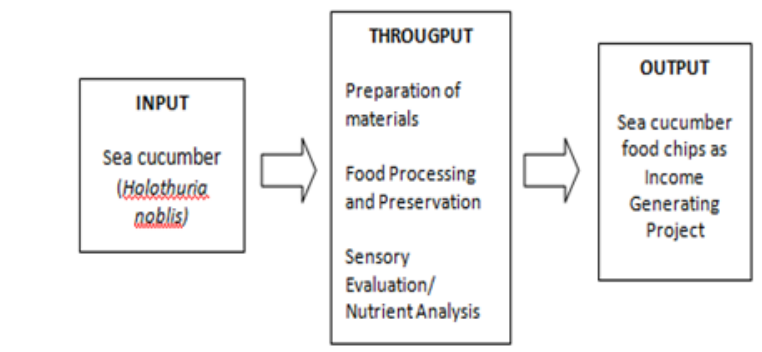

Figure. 1, The diagram showing the processing sea cucumber chips as viable income generating project.

\section{METHODOLOGY}

\section{A. Research Design}

The purpose of this study was to find out the acceptability of sea cucumber (Holothuria nobilis) chips as well as its nutritional value as a food product, a descriptive-survey method of research was employed with an evaluation sheet as the main instrument. Through Costumers' Preference Testing/Sensory Evaluation, sea cucumber chips were categorically evaluated.

\section{B. Research Environment}

The processing of food was conducted at the HRM food laboratory, Palompon Institute of Technology, Palompon, Leyte.

\section{Research Respondents}

The respondents were the faculty/ employees, food technology students, and food caterers operating within the Poblacion of Palompon, Leyte. The sex and age distribution of respondents were shown in Table 1 and 2.

TABLE I: SEX DISTRIBUTION OF THE RESPONDENTS

\begin{tabular}{ccc}
\hline Sex & Frequency & Percentage \\
\hline Male & 12 & 40 \\
Female & 18 & 60 \\
\hline Total & 30 & $100 \%$
\end{tabular}

The respondents were predominantly female. There were 12 males or an equivalent of $40 \%$ of the respondents, while there were 18 females or an equivalent of $60 \%$. The majority was women and most of them are engaged in cooking or making pastries because this undertaking requires less intense labor.

TABLE 2: AGE DISTRIBUTION OF THE RESPONDENTS

\begin{tabular}{ccc}
\hline Age & Frequency & Percentage \\
\hline 60 or more & 1 & 3.33 \\
$40-59$ & 4 & 13.33 \\
$30-39$ & 9 & 30.00 \\
$15-29$ & 16 & 53.34 \\
\hline Total & 30 & $100.00 \%$
\end{tabular}

The most number of the respondents are found in the 15-29 age groups. Then of a significant number or nine (9) are the respondents in the $30-39$ age bracket, the same number of four (4) are within 40 - 59 age groups and only one (1) belongs to 60 or more age group. Inasmuch as most respondents are in the younger aged group, most of them have good sensory-testing evaluations and they are expected to have enough exposures to any cooking activities while in school or in the work place.

\section{Procedures}

a. Conduct a preliminary investigation about the research project and preparation of materials, instruments, documents, permits, etc. in the conduct of the study.

b. Placed the collected samples in a bucket of seawater

c. Upon return to the laboratory, the samples are rinsed off in seawater to remove excess salt. Mark the sample using a marker pen, then let it dry on a plastic tray to remove excess water and weigh.

d. Samples will then replace in plastic bags and put in a subzero freezer for approximately one day.

e. Process in making sea cucumber food chips

1. Preparation of materials, equipment, and other ingredients; 2. sand scrubbed the sea cucumber, 3 . wash with boiling water; 4. drain the washing, and skin of the said sea cucumber; 5. slice each sea cucumber longitudinally and remove and internal parts out of the body, then wash the sea cucumber with warm tap water; 6. wash again with vinegar, drain and wash with warm tap water; 7. slicing the said cucumber into thin rectangular pieces; 8. soak overnight with 1 cup of vinegar, lemon juice (extracted from 5 pcs lemon), 5 small packs of black pepper, 1 table spoon of slat, $1 / 2$ small pack of MSG.; 9 . drain the marinate sauce and place the said cut sea cucumber on a screen; 10. exposing the screen with the cut sea cucumber to the sun for drying; 11 . Cook in 15 minutes and fry the sea cucumber in the desired temperature.

\section{E. Research Instrument}

The analysis and interpretation were based upon the evaluation sheet as rated by the food technology instructors, students, and food caterers.

\section{F. Treatment of Data}

In order to determine the level of acceptability, the weighted mean was used. 


$$
\overline{\mathrm{X}}=\frac{\sum \mathrm{fx}}{\mathrm{N}}
$$

Where:

$$
\begin{aligned}
& \mathrm{X}^{-}=\text {weighted mean } \\
& \sum=\text { summation } \\
& \mathrm{f}=\text { frequency of distribution } \\
& \mathrm{X}=\text { weight assigned to each scale } \\
& \mathrm{N}=\text { number of respondents }
\end{aligned}
$$

To determine the significant difference among the food technology instructors, students and food caterers, the one-way analysis of variance (ANOVA) was employed.

$$
\mathrm{F}=\frac{\mathrm{MSb}}{\mathrm{MSw}}
$$

Where:

$$
\begin{array}{ll}
\mathrm{F} & =\text { ratio } \\
\mathrm{MSb} & =\text { the mean square between groups } \\
\mathrm{MSw} & =\text { the mean square within groups }
\end{array}
$$

\section{G. Scoring Procedure}

To interpret the level of acceptability of sea cucumber (Holothuria nobilis) food chips, a rating code and a rating equivalent were used.

$\begin{array}{ccl}\begin{array}{c}\text { Weights } \\ 5\end{array} & \begin{array}{c}\text { Range } \\ 4.21-5.00\end{array} & \begin{array}{l}\text { Interpretation } \\ \text { Very much } \\ \text { acceptable }\end{array} \\ 4 & 3.41-4.20 & \begin{array}{l}\text { Very acceptable } \\ \text { Acceptable }\end{array} \\ 2 & 2.61-3.40 & \text { Fairly acceptable } \\ 1 & 1.81-2.60 & \text { Not acceptable }\end{array}$

\section{RESULTS AND DISCUSSIONS}

\section{A. Nutrient analysis of samples}

The samples from the collecting sites were subjected to nutrients analysis. The samples were put in labeled plastic bags, subsequently preserved in a 7\% formaldehyde solution and then transported to the laboratory Department of Animal Science, College of Agriculture and Food Science, VSU Baybay Leyte Philippines for proximate analysis of the sample using standard methods (AOAC, Official Method of Analysis, 2000) as shown in Table 3.

TABLE III. PROXIMATE NUTRIENT ANALYSIS OF SAMPLES FROM THE COLLECTING SITE

\begin{tabular}{lccccc}
\hline \multirow{2}{*}{ Samples } & \multicolumn{5}{c}{ Proximate Composition (\%) } \\
\cline { 2 - 6 } & Moisture & Protein & Fat & Dry Matter & Ash \\
\hline $\begin{array}{l}\text { Sea } \\
\text { cucumber }\end{array}$ & 87.15 & 36.47 & 0.98 & 12.85 & 5.52 \\
\hline
\end{tabular}

t has shown that sea cucumber has high moisture content but it has very low in fat and high value in protein. The dry matter and ash are the indications of the presence of mineral contents. Normally, sea cucumbers are the rich source of potassium and are relatively low in calories. (http://www.issc.org/clams).

B. Acceptability of sea cucumber food chips in terms of appearance, crispiness, and flavor as perceived by different groups of evaluators.

The visual identification of quality food chips is based on the color and texture. The sea cucumber food chips should look like real chips in the market so as to attract the consumer to buy the product. The level of acceptability of sea cucumber food chips in terms of appearance was shown in Table 4.

TABLE IV. LEVEL OF ACCEPTABILITY OF SEA CUCUMBER FOOD CHIPS IN TERMS

\begin{tabular}{lcc} 
& \multicolumn{1}{c}{ OF APPEARANCE. } \\
\hline \multicolumn{1}{c}{$\begin{array}{c}\text { Group of } \\
\text { evaluators }\end{array}$} & $\overline{\mathrm{X}}$ & Interpretation \\
\hline $\begin{array}{l}\text { Food/culinary } \\
\text { instructors }\end{array}$ & 4.5 & Very much acceptable \\
$\begin{array}{l}\text { Food technology } \\
\text { students }\end{array}$ & 4.5 & Very much acceptable \\
$\begin{array}{l}\text { Food caterers } \\
\text { Average mean }\end{array}$ & 4.1 & Very acceptable \\
\hline
\end{tabular}

As shown in Table 4, only the food caterers rated the sea cucumber food chips appearance as very acceptable with a weighted mean of 4.1 and food/ culinary instructors and students rated the sea cucumber food chips as very much acceptable with weighted means of 4.5. This goes to show that there is no really need to improve the appearance of the sea cucumber food chips in order to attract the consumer in patronizing the product.

On the other hand, the level of acceptability of sea cucumber food chips in terms of crispiness was shown in Table 5. Crispiness depends on the amount of moisture retained in the food product. Crispiness increases its quality and flavor and making easier it easier to chew.

TABLE V. LEVEL OF ACCEPTABILITY OF SEA CUCUMBER FOOD CHIPS IN TERMS

\begin{tabular}{lcc}
\multicolumn{1}{c}{ OF CRISPINESS } \\
\hline $\begin{array}{l}\text { Group of } \\
\text { Evaluators }\end{array}$ & $\overline{\mathrm{X}}$ & Interpretation \\
\hline $\begin{array}{l}\text { Food/culinary } \\
\text { instructors }\end{array}$ & 4.5 & Very much acceptable \\
$\begin{array}{l}\text { Food technology } \\
\text { students }\end{array}$ & 4.3 & Very much acceptable \\
$\begin{array}{l}\text { Food caterers } \\
\text { Average mean }\end{array}$ & 4.4 & Very much acceptable \\
\end{tabular}

As presented in Table 5, all the evaluators agree that sea cucumber food chips really passed the crispiness quality as reflected in the food caterers weighted mean of 4.4, food/ culinary instructors of 4.5 , and 4.3 for the food technology students. It shows a very remarkable weighted mean of 4.4 , categorized as very much acceptable.

It is implied that there is no problem as to the crispiness of the sea cucumber food chips and the data indicated a positive indication of sea cucumber food chips being a viable product.

Table 6 shows a significance acceptance in terms of flavor. Flavor and odor are intertwined to create the sensation of the consumer upon eating. These perceptions rely on the smell through the nose and on the sensations of salty, sweet, sour and bitter on the tongue. 
TABLE VII SUMMARY OF EVALUATION FROM THE THREE GROUP OF EVALUATORS

\begin{tabular}{lcc}
\multicolumn{2}{l}{ TABLE VI. LEVEL OF ACCEPTABILITY OF SEA CUCUMBER FOOD CHIPS IN TERMS } \\
& OF FLAVOR & \\
\hline Group of Evaluators & $\overline{\mathrm{X}}$ & Interpretation \\
\hline $\begin{array}{l}\text { Food/ culinary } \\
\text { instructors }\end{array}$ & 4.2 & Very much acceptable \\
$\begin{array}{l}\text { Food technology } \\
\text { students }\end{array}$ & 4.2 & Very much acceptable \\
$\begin{array}{l}\text { Food caterers } \\
\quad\end{array}$ & 3.9 & Very acceptable \\
\multicolumn{1}{l}{ Average mean } & 4.2 & Very much acceptable \\
\hline
\end{tabular}

\begin{tabular}{|c|c|c|c|}
\hline \multirow{2}{*}{$\begin{array}{c}\text { Average } \\
\text { Mean }\end{array}$} & \multicolumn{3}{|c|}{ Criteria } \\
\hline & Appearance & ipiness & Flavor \\
\hline $\begin{array}{l}\text { Food/ culinary } \\
\text { instructors }\end{array}$ & 4.5 & 4.5 & 4.4 \\
\hline Food tech students & 4.5 & 4.3 & 4.2 \\
\hline Food caterers & 4.1 & 4.4 & 3.9 \\
\hline Total ave. mean & 4.4 & 4.4 & 4.2 \\
\hline Grand mean & \multicolumn{3}{|c|}{4.3} \\
\hline
\end{tabular}

As reflected in Table 6, only the food caterers with a very acceptable flavor of sea cucumber food chips by giving a 3.9 weighted mean and both food technology students and culinary instructors rated flavor as very much acceptable with weighted means of 4.2.

The next table shows the summary of evaluation from the three groups of evaluators.

4.3 , categorized as very much acceptable. Though appearance, crispiness, and flavor were not related but still was categorized very much acceptable. It shows that sea cucumber food chips are really a viable source for income generation.

The table below exposes the significant difference in the level of acceptability of sea cucumber food chips sea cucumber food chips as evaluated by the food/ culinary instructors, food tech. students and food caterers.

B. Summary

\begin{tabular}{lcccc}
\hline \multicolumn{1}{c}{ Groups } & Count & Sum & Average & Variance \\
\hline Appearance & 3 & 13.1 & 4.37 & 0.05 \\
Crispiness & 3 & 13.2 & 4.40 & 0.01 \\
Flavor & 3 & 12.5 & 4.17 & 0.06 \\
\hline
\end{tabular}

ANOVA

\begin{tabular}{ccccccc}
\hline $\begin{array}{c}\text { Source of } \\
\text { Variation }\end{array}$ & $\begin{array}{c}\text { Sum of } \\
\text { squares }\end{array}$ & $\mathrm{df}$ & $\begin{array}{c}\text { Mean } \\
\text { square }\end{array}$ & $\mathrm{F}$ & P-value & $\mathrm{F}$ crit \\
\hline Between Groups & 0.096 & 2 & 0.048 & 1.13 & 0.38 & 5.14 \\
Within Groups & 0.253 & 6 & 0.042 & & & \\
& & & & & & \\
Total & 0.349 & 8 & & & & \\
\hline
\end{tabular}

By using the one-way analysis of variance (ANOVA), the difference in the average mean ratings of the three groups of evaluators was statistically tested with the critical value of $\mathrm{F}$ at 0.05 level of significance. It was found out that the obtained value of 1.13 was less than the table value of 5.14. Hence, the difference was not significant at all.

Thus, the null hypothesis is accepted and therefore, the evaluators' assessments were the same.

\section{CONCLUSION}

Based on the findings of the study, sea cucumber food chips is really a source for income generation as reflected in the grand mean of 4.3 , categorized as very much acceptable. Although, there are some qualitative attributes of the sea cucumber food chips that were not highly acceptable, such as the appearance and flavor as perceived by food caterers but it can be improved through food enhancers and additives.
Therefore, there is no doubt that sea cucumber food chips is a good source for income generation as well as very good source of achieving good health.

\section{RECOMMENDATIONS}

It is highly recommended that sea cucumber food chips production be a part of food laboratory activities as this is a good source for income generation.

It is highly requested that the canteen management and other tourism services office in Palompon, Leyte shall allow selling sea cucumber food chips as one way of promoting the said product.

It is also recommended that food technology instructors and students shall disseminate to all mothers in the community that sea cucumber food chips has a good source of nutritional value. 


\section{REFERENCES}

[1] Gilliland, P. M. 1993. The skeletal morphology, systematics and evolutionary history of holothurians. Special Papers in Palaeontology 47: $1-147$

[2] Hyman, L. H. 1955. The Invertebrates. Vol. 4. Echinodermata. New York: McGraw Hill.

[3] Kerr, A. 2000. Evolution and Systematics of Holothuroidea (Echinodermata). Thesis, Yale University.

[4] Mooi, R. and B. David. 1997. Skeletal homologies of echinoderms. Paleontological Society Papers 3: 305-355.

[5] Pawson, D. L. 1982. Holothuroidea. In: Parker, S. P., ed. Synopsis and Classification of Living Organisms. New York: McGraw-Hill, 813-818.

[6] Semper, C. 1868. ReisenimArchipel der Philippinen. 2. WissenschaftlicheResultate. 1. Holothurien. Leipzig: Wilhelm Engelmann.

[7] Smiley, S., F. S. McEuen, S. Chaffee, and S. Krishnan. 1991. Echinodermata: Holothuroidea. In: Giese, A. C., J. S. Pearse, and V. B. Pearse, eds. Reproduction of Marine Invertebrates. Volume 6. Pacific Grove, California: Boxwood Press, 663-750.

[8] Smiley, S. 1994. Holothuroidea. In: Harrison, F. W. and F.-S. Chia, eds. Microscopic Anatomy of Invertebrates. Volume 14. Echinodermata. New York: Wiley-Liss, 401-471.
[9] Smith, A. B. 1997. Echinoderm larvae and phylogeny. Annual Review of Ecology and Systematics 28: 219-241.

[10] Philippine Council for Aquatic \& Marine (PCAMRD-DOST). Jamboree Rd., Brgy. Timugan, Los Banos, Laguna,

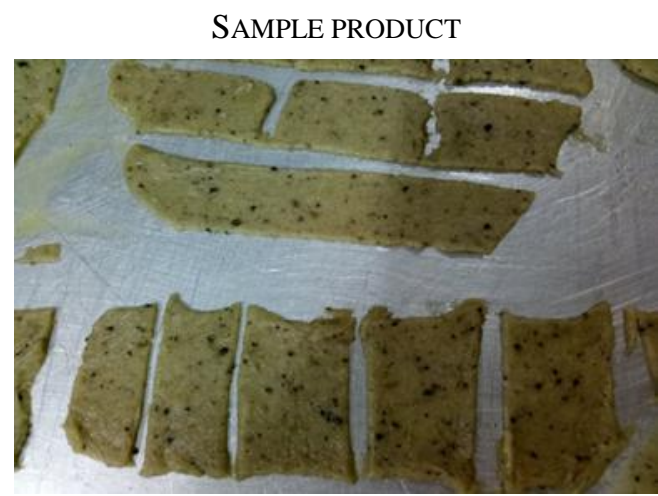

Sea cucumber chips 